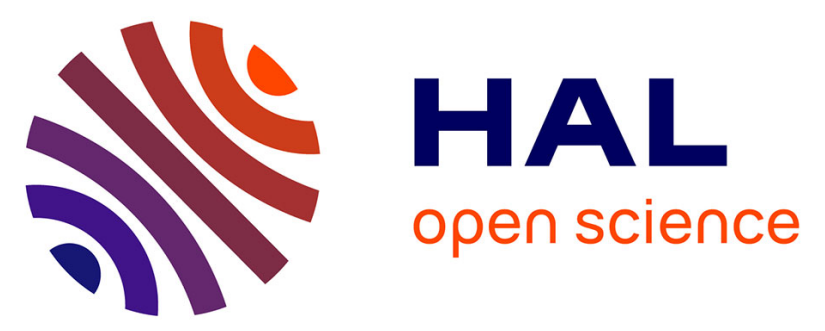

\title{
Revisiting the neural role of estrogen receptor beta in male sexual behavior by conditional mutagenesis
}

Lydie Naulé, Clarisse Marie-Luce, Caroline Parmentier, Mariangela Martini, Christelle Albac, Anne-Charlotte Trouillet, Matthieu Keller, Hélène Hardin-Pouzet, Sakina Mhaouty-Kodja

\section{To cite this version:}

Lydie Naulé, Clarisse Marie-Luce, Caroline Parmentier, Mariangela Martini, Christelle Albac, et al.. Revisiting the neural role of estrogen receptor beta in male sexual behavior by conditional mutagenesis. Hormones and Behavior, 2016, 80, pp.1-9. 10.1016/j.yhbeh.2016.01.014 . hal-01297466

\section{HAL Id: hal-01297466 https://hal.sorbonne-universite.fr/hal-01297466}

Submitted on 4 Apr 2016

HAL is a multi-disciplinary open access archive for the deposit and dissemination of scientific research documents, whether they are published or not. The documents may come from teaching and research institutions in France or abroad, or from public or private research centers.
L'archive ouverte pluridisciplinaire HAL, est destinée au dépôt et à la diffusion de documents scientifiques de niveau recherche, publiés ou non, émanant des établissements d'enseignement et de recherche français ou étrangers, des laboratoires publics ou privés. 
2 Title: Revisiting the neural role of estrogen receptor beta in male sexual behavior by

3 conditional mutagenesis

4 Author names and affiliations:

5 Lydie Naule ${ }^{123^{*}}$, Clarisse Marie-Luce ${ }^{123^{*}}$, Caroline Parmentier ${ }^{123}$, Mariangela Martini ${ }^{4567}$,

6 Christelle Albac $^{123}$, Anne-Charlotte Trouillet ${ }^{123}$, Matthieu Keller ${ }^{4567}$, Hélène Hardin-

$7 \quad$ Pouzet $^{123}$, Sakina Mhaouty-Kodja ${ }^{123}$

8

$9{ }^{1}$ Neuroscience Paris Seine, Institut National de la Santé et de la Recherche Médicale, Unité

10 Mixte de Recherche (UMR) S1130, Université P. et M. Curie, Paris, France

$11{ }^{2}$ Centre National de la Recherche Scientifique, UMR 8246, Université P. et M. Curie, Paris,

12 France

$13{ }^{3}$ Sorbonne Universités, Université P. et M. Curie UM CR18, Université Paris 06, France.

$14{ }^{4}$ UMR 85, Institut National de la Recherche Agronomique, Nouzilly, France

$15{ }^{5}$ UMR7247, Centre National de la Recherche Scientifique, Nouzilly, France

$16{ }^{6}$ Université François Rabelais, Tours, France

$17{ }^{7}$ Institut Français du Cheval et de l'Equitation, Nouzilly, France.

18 *Equal contribution

19 Corresponding author:

20 Sakina Mhaouty-Kodja

21 Université P. \& M. Curie, 7 quai St Bernard, Bât A 3ème étage, Paris CEDEX 05

22 e.mail address: sakina.mhaouty-kodja@upmc.fr

23 Phone number: +33-1 44279138

24 Fax number: +33-144272508 

the phenotype of global $E R \beta$ knockout models are discussed.

\section{Abstract} mutant males.

Estradiol derived from neural aromatization of gonadal testosterone plays a key role in the perinatal organization of the neural circuitry underlying male sexual behavior. The aim of this study was to investigate the contribution of neural estrogen receptor (ER) $\beta$ in estradiolinduced effects without interfering with its peripheral functions. For this purpose, male mice lacking $E R \beta$ in the nervous system were generated. Analyses of males in two consecutive tests with a time interval of two weeks showed an effect of experience, but not of genotype, on the latencies to the first mount, intromission, pelvic thrusting and ejaculation. Similarly, there was an effect of experience, but not of genotype, on the number of thrusts and mating length. Neural $E R \beta$ deletion had no effect on the ability of males to adopt a lordosis posture in response to male mounts, after castration and priming with estradiol and progesterone. Indeed, only low percentages of both genotypes exhibited a low lordosis quotient. It also did not affect their olfactory preference. Quantification of tyrosine hydroxylase- and kisspeptinimmunoreactive neurons in the preoptic area showed unaffected sexual dimorphism of both populations in mutants. By contrast, the number of androgen receptor- and ER $\alpha$ immunoreactive cells was significantly increased in the bed nucleus of stria terminalis of

These data show that neural ER $\beta$ does not play a crucial role in the organization and activation of the neural circuitry underlying male sexual behavior. These discrepancies with 


\section{$47 \quad$ Keywords}

48 Sex steroid hormones; Estrogen receptor beta; Nervous system; Estradiol; Sexual behavior;

49 Conditional mutagenesis, Male reproduction; Sexual dimorphism

50 


\section{Introduction}

In male rodents, sexual behavior is induced by olfactory cues. Pheromonal cues are transmitted from the main olfactory epithelium and vomeronasal organ to, respectively, the main and accessory olfactory bulbs, then to chemosensory responsive nuclei in the medial amygdala (MeA), bed nucleus of stria terminalis (BNST), and medial preoptic area (MPOA) where they are processed in behavioral responses. This neural circuitry is under the tight control of gonadal hormones. Estradiol derived from neural aromatization of perinatal testosterone induces irreversible masculinization and defeminization processes (Schwarz and McCarthy, 2011). Masculinization is the potentiation of neuroanatomical and behavioral patterns that are exhibited to a greater degree by males than females (e.g., preference for receptive females and copulatory behaviors). Defeminization is the loss of the ability to display female-typical behaviors such as preference for males and receptive mating posture (lordosis). The organizational effects of estradiol result in sex differences at the structural, neurochemical and molecular levels along the circuitry involved in the control of sexual behavior and reproductive functions. For instance, a cluster of calbindin-immunoreactive neurons in the MPOA, corresponding to the rat sexually dimorphic nucleus involved in sexual behavior, contains more cells in males than in females (Orikasa and Sakuma, 2010). Inversely, neurons expressing tyrosine hydroxylase (TH) or kisspeptin are less numerous in males compared to females in the anteroventral periventricular nucleus (AVPV), a subdivision of the medial preoptic area involved in the ovulatory surge of LH (Clarkson and Herbison, 2006; Kauffman et al., 2007; Simerly et al., 1985). genes. Genetic studies highlighted the role of ER $\alpha$ in male reproduction and expression of male sexual behavior since global ER $\alpha$ knockout males are infertile and exhibit impaired 
behavior (Ogawa et al., 1997; Ogawa et al., 1998; Wersinger et al., 1997). The involvement of ER $\beta$ in estradiol-induced effects needs further clarification. The analysis of the first genetic model with global $E R \beta$ deletion (Krege et al., 1998) showed that mutant males are fertile and display normal sexual behavior and olfactory preference (Kudwa et al., 2005; Ogawa et al., 1999). A transient effect of $E R \beta$ deletion was observed around the time of puberty since peripubertal mutants displayed delayed ejaculation behaviour (Temple et al., 2003). When mutant males were castrated at adulthood and primed with estradiol and progesterone, they displayed a higher lordosis behavior than wild-types (Kudwa et al., 2005). At the neuroanatomical level, it was found that the number of TH-immunoreactive cells was increased in the AVPV region of mutant males by comparison to wild-types (Bodo et al., 2006). This suggested that ER $\beta$ mediates the estradiol-induced defeminization of the male brain. Global $E R \beta$ deletion also affected the sexually dimorphic expression of ER $\alpha$ in the preoptic area (Temple et al., 2001). By contrast, in the BNST, the volume and neuronal number, which are more important in males than females, were not affected (Tsukahara et al., 2011). More recently, a global $E R \beta$ knockout mouse line, devoid of any $E R \beta$ transcript, was generated by using the Cre-loxP system (Antal et al., 2008). These mutant males are infertile and exhibit mildly impaired sexual behavior (Antal et al., 2012). They display higher numbers of mounts and intromissions as well as delayed ejaculation, but these deficits were improved by sexual experience. In this mouse model, the involvement of ER $\beta$ in the defeminization processes of the male brain has not been studied.

Although useful, the global genetic models limit the understanding of the neural contribution of $\operatorname{ER} \beta$, due to the ubiquitous nature of the gene deletion. Estrogens through ER $\beta$ which is expressed in the testis, epididymis and prostate (Saunders et al., 1998; van Pelt et al., 1999), play also a role in the physiology of the male urogenital tract (Imamov et al., 2004; Sar 
101 and Welsch, 2000; Wahlgren et al., 2008). The present study was undertaken in order to 102 investigate the neural implication of ER $\beta$ in the masculinization and defeminization of the 103 neural circuitry underlying male sexual behavior, without interference with its peripheral 104 functions. For this purpose, we generated a mouse line lacking $E R \beta$ in the nervous system by 105 using Cre-loxP technology. Male sexual behavior was analyzed in both naïve and sexually 106 experienced males in the presence of receptive females. The ability of males to adopt lordosis

107 posture in response to mounts of stud males was also analyzed. The effects of neural $E R \beta$ 108 mutation on the organization of $\mathrm{TH}$ - and kisspeptin-immunoreactive neurons located in the 109 sexually dimorphic rostral periventricular area of the third ventricle (RP3V) were 110 investigated. Finally, the potential impact of neural $E R \beta$ deletion on the expression of 111 androgen receptor (AR) and $\mathrm{ER} \alpha$ expression was evaluated in brain areas underlying male 112 sexual behavior. 


\section{Animals}

116 The ER $\beta^{\text {NesCre }}$ mouse line was obtained, on a C57BL/6J genetic background, by crossing

117 floxed $E R \beta$ females in which exon 3 of $E R \beta$ was flanked by loxP sites (Antal et al., 2008)

118 with floxed $E R \beta$ males expressing the Cre recombinase under the control of the rat nestin

119 (Nes) promoter and neural-specific enhancer (Raskin et al., 2009) as recently described

120 (Naulé et al., 2015). Cre-mediated excision of floxed exon 3 of the $E R \beta$ gene allows the

121 deletion of all $E R \beta$ transcripts (Antal et al., 2008). Mutant mice (ER $\beta^{\mathrm{fl} / \mathrm{fl}}$ carrying the NesCre 122 transgene; $\left.\mathrm{ER} \beta^{\mathrm{NesCre}}\right)$ and their control littermates $\left(\mathrm{ER} \beta^{\mathrm{fl} / \mathrm{fl}}\right)$ were group-housed under a controlled photoperiod (12:12-h light-dark cycle - lights on at 7 am), maintained at $22^{\circ} \mathrm{C}$, with free access to food and water. All studies were performed on 2-4 months old animals, in accordance with the European guidelines for use of experimental animals (Decree 87-848, 86/609/ECC). Experiments were performed accordingly, to minimize animal number and discomfort and were approved by the local Department of Animal Protection and Health.

\section{PCR and RT-PCR}

130 Neural ER $\beta$ invalidation was confirmed by both PCR and RT-PCR. The lack of antibodies specific enough against ER $\beta$ receptor (Snyder et al., 2010) did not allow analyses at the

132 protein level. For PCR, detection of the Cre recombinase and $E R \beta$ alleles in DNA extracts

133 from adult and neonatal brains was performed as previously described (Antal et al., 2008;

134 Raskin et al., 2009). For RT-PCR, total RNAs were extracted from the brain and epididymis 135 using Trizol reagent (Invitrogen, Carlsbad, USA). RNA (2 $\mu \mathrm{g})$ was reverse transcribed using 136 the Superscript III first strand Synthesis System (In vitrogen). PCR reactions were performed 137 using the resulting cDNA, Taq DNA pol (In vitrogen), dNTPs (10 nM each), forward (5'138 CAGAGAGACCCTGAAGAGGA-3') and reverse (5'-CCTTGAATGCTTCTTTTAAA-3') 
139 primers for ER $\beta$ (Antal et al., 2008) and for GAPDH (forward:

140 TGCACCACCAACTGCTTAGC; reverse: GGCATGGACTGTGGTCATGAG) in a

141 MyCycler Thermal Cycler (Bio Rad, Marne la Coquette, France). The amplified cDNA

142 fragments were separated by electrophoresis through a 1.5\% agarose gel and stained by

143 ethidium bromide.

144

145 Urogenital tract, hormone levels and fertility

146 Intact animals were sacrificed to collect blood and to weigh seminal vesicles. Sera were

147 extracted and circulating levels of testosterone were measured by RIA at the hormonal assay

148 platform of the laboratory of behavioral and reproductive physiology (UMR 7247

149 INRA/CNRS/Université François Rabelais) using ${ }^{3} \mathrm{H}-\mathrm{T}$, as previously described (Picot et al.,

150 2014). The mean intra-assay coefficient of variation was 7\% and assay sensitivity was 125

$151 \mathrm{pg} / \mathrm{ml}$.

152 To evaluate fertility, three months-old males ( 4 per genotype) were mated for 4 months. Each

153 male was individually housed with two age-matched females. The number of pups and the 154 interval from mating to the first litter were recorded.

156 Behavioral analyses

157 Tests were conducted under red-light illumination 2 hours after lights-off and videotaped for 158 analyses.

$160 \quad$ Male-typical behaviors of intact males

161 Male sexual behavior

162 Intact animals were individually housed 3 days before the first test. Each male was tested in

163 its home cage for $10 \mathrm{~h}$ after the introduction of an estrus female. They were tested twice with 
164 a time interval of two weeks. Male sexual behavior was analyzed by scoring the latency and

165 the frequency of mounts, intromissions, thrusts and ejaculation as previously described

166 (Raskin et al., 2009). Estrus C57BL/6J females used as stimuli were ovariectomized under

167 general anesthesia (xylazine $10 \mathrm{mg} / \mathrm{kg} / \mathrm{ketamine} 100 \mathrm{mg} / \mathrm{kg}$ ), implanted with SILASTIC

168 implants filled with $50 \mu \mathrm{g}$ of estradiol-benzoate (Sigma-Aldrich, Saint Louis, United States)

169 in $30 \mu \mathrm{l}$ of sesame oil and subcutaneously treated with $1 \mathrm{mg}$ of progesterone (Sigma-Aldrich)

170 in $100 \mu \mathrm{l}$ of sesame oil four to five hours before the tests, as previously reported (Raskin et

171 al., 2009). Female receptivity was verified before the beginning of experiments as following.

172 Each female was put in the presence of a sexually experienced male, which was not in contact

173 with a female for at least 1 week. The female was considered receptive when she displayed a

174 lordosis posture with the four paws grounded, the hind region lifted and the back arched in

175 response to male mounts.

176 For each male, the latencies from female introduction to the first mount, intromission,

177 thrusting and to ejaculation were measured. The total number of mounts, without and with

178 intromissions, and the total number of thrusts were measured. Mating length was defined as

179 the time from the first mount to ejaculation.

180

181

Olfactory preference

182 Sexually experienced males were placed into an enclosed Plexiglas Y-maze without any

183 stimuli, for $5 \mathrm{~min}$ on two consecutive days, to allow them to adapt to the apparatus. Animals

184 were tested for mate preference on the third day by placing an anesthetized receptive female

185 and gonadally intact male in boxes with perforated partitions at the end of each distal arm as

186 previously described (Keller et al., 2006). The time spent sniffing at each partition was scored

187 over the five-minute test. Results are expressed as a percentage of total time spent sniffing 
male or female cues. The maze was cleaned with $10 \%$ ethanol between trials (Naulé et al., 2014).

191 Female-typical behaviors of castrated males primed with estradiol and progesterone

192 Lordosis behavior

193 Males $\left(22 \mathrm{ER} \beta^{\mathrm{fl} / \mathrm{fl}}\right.$ and $21 \mathrm{ER} \beta^{\mathrm{NesCre}}$ mice) were castrated under general anesthesia (xylazine /

194 ketamine). Four weeks later, they were tested for female sexual behavior in three consecutive 195 tests conducted at one-week interval as previously described (Picot et al., 2014). Briefly, 196 subjects were subcutaneously injected with estradiol-benzoate $(10 \mu \mathrm{g}$ dissolved in $100 \mu \mathrm{l}$ of 197 sesame oil) $48 \mathrm{~h}$ prior to the test and progesterone (1 $\mathrm{mg}$ in $100 \mu \mathrm{l}$ of sesame oil) four hours 198 before the tests. Experimental males were put in the presence of sexually experienced 199 C57BL/6J male mice serving as stimulus animals. Tests ended when the subject received 20 200 mounts or after 20 minutes of test. The lordosis posture in response to stud male mounting 201 was determined as mentioned above. The lordosis quotient was calculated only for the males, 202 which received 20 mounts, as the number of times the male adopts a lordosis-like posture in 203 response to stimulus male mount. A group of females $(n=10)$ used as controls for the 204 lordosis behavior test was ovariectomized, implanted with estradiol and primed with 205 progesterone as described above. They were tested twice in the presence of stud males at one206 week interval.

Olfactory preference

209 Tests were performed as described above for intact males. Males castrated and primed with 210 estradiol and progesterone were tested 1 week after lordosis behavior tests.

\section{Immunohistochemistry}


213 Intact males were sacrificed and transcardially perfused with a solution of 4\% 214 paraformaldehyde (PFA) in phosphate buffer (PB). Brains were post-fixed overnight in 4\% 215 PFA-PB, cryoprotected in sucrose and stored until analyses. They were sliced into coronal 216 sections of $30 \mu \mathrm{m}$ using a cryotome (Leica CM 3000). Kisspeptin, AR- and ER $\alpha$ 217 immunostaining were carried as previously described (Naulé et al., 2014; Picot et al., 2014). 218 For TH- immunostaining, the sections were blocked for $2 \mathrm{~h}$ with $2 \%$ normal donkey serum 219 (Sigma-Aldrich) in PB saline (PBS) containing $0.1 \%$ Triton-X100 and $0.25 \%$ human 220 albumin, then incubated with polyclonal anti-TH antibody (1:5000; Chemicon, Temecula, 221 United States) overnight. Immunofluorescence was performed with a CY3 donkey anti-rabbit 222 secondary antibody (1:500, Jackson Immunoresearch, Montlucon, France) for $2.5 \mathrm{~h}$ at room 223 temperature. After several rinses in PBS, sections were rinsed in water, dried, mounted in 224 Fluoromount-G (Southern Biotechnology, Birmingham, AL, USA) under a coverslip and 225 stored at $4{ }^{\circ} \mathrm{C}$ in the dark.

226 The numbers of kisspeptin-, TH-, AR and ER $\alpha$-immunoreactive cells were counted in 227 anatomically matched sections identified using the Mouse Brain Atlas of Paxinos and 228 Franklin (2001) as previously described (Naulé et al., 2014; Picot et al., 2014). Kisspeptin229 immunoreactive cells were analyzed within each of the three subdivisions of the rostral 230 periventricular area of the third ventricle within an area of $0.24 \mathrm{~mm}^{2}$ including the AVPV 231 nucleus (plates 28-29) and the preoptic periventricular nucleus, divided into rostral (plate 30) 232 and caudal regions (plates 31-32). TH-immunoreactive cells were counted in the AVPV 233 within an area of $0.24 \mathrm{~mm}^{2}$ (plates 27-31). AR and ER $\alpha$-immunoreactive cells were analyzed 234 in the MPOA within an area of $0.68 \mathrm{~mm}^{2}$, in the BNST within an area of $0.70 \mathrm{~mm}^{2}$ (plate 30), 235 and in the MeA within an area of $0.56 \mathrm{~mm}^{2}$ (plate 47 ). 
238 Data were expressed as mean \pm S.E.M. Student's t-tests were used to determine the effect of 239 genotype on circulating levels of testosterone, weight of seminal vesicles and fertility. Effect 240 sizes were further estimated by calculating the Cohen's $d(d=M / S D$, where $M$ is the mean of 241 differences and SD is the standard deviation of differences; $d=0.2$ is considered as a small 242 effect size, $\mathrm{d}=0.5$ as a medium effect size and $\mathrm{d}=0.8$ as a large effect size). Two-way 243 ANOVA was used to analyze the main effects of genotype and experience on male sexual 244 behavior and lordosis quotient or genotype and stimulus on olfactory preference. Tukey post245 hoc tests were used to determine group differences. Effect sizes were further estimated by 246 calculating the eta-squared $\eta^{2}\left(\eta^{2}=\mathrm{SS}_{\text {effect }} / \mathrm{SS}_{\text {total }}\right.$, where $\mathrm{SS}_{\text {effect }}$ is the sums of squares for the 247 effect of interest and $\mathrm{SS}_{\text {total }}$ is the total sums of squares for all effects, interactions and errors, $248 \eta^{2}=0.02$ is considered as a small effect size, $\eta^{2}=0.13$ as a medium effect size and $\eta^{2}=0.26$ 249 as a large effect size). As variances were not homogeneous between groups, TH-, kisspeptin250 ER $\alpha$ - and AR immnunoreactivity was analyzed with Mann-Whitney nonparametric test. P 251 values of less than 0.05 were considered to be significant. 


\section{Results}

\section{General characterization of the $\operatorname{ER} \beta^{\mathrm{Nes} C r e}$ mouse line}

255 The selective neural deletion of $E R \beta$ was confirmed by RT-PCR. A 177 bp-amplified

256 fragment was present at comparable levels of expression in the epididymis of ER $\beta^{\mathrm{fl} / \mathrm{fl}}$ and $257 E R \beta^{\text {NesCre }}$ males $(t=-2.543, p=0.064, d=-2.540)$. This signal was present in the brain of $258 E R \beta^{\mathrm{fl} / \mathrm{fl}}$ males, and highly reduced in their $\mathrm{ER} \beta^{\mathrm{NesCre}}$ littermates $(-98 \%, \mathrm{t}=7.716, p=0.001, \mathrm{~d}$ $259=7.660$; Fig. 1A-B). The NesCre transgene used triggers gene deletion in neural precursor 260 cells by embryonic day 10.5 , before gonadal differentiation. To ensure that excision of neural $E R \beta$ exon 3 was indeed efficient during the perinatal organization of the male brain, we performed a PCR analysis for $E R \beta$ alleles and Cre recombinase on DNA extracted from neonatal and adult brains. A small amplicon of $250 \mathrm{bp}$ indicating Cre-mediated excision of $E R \beta$ exon 3 was found in the brain of both neonatal and adult males expressing the Cre recombinase (Fig. 1C). By comparison, a $850 \mathrm{bp}$ signal corresponding to the floxed allele was seen in the brain of control littermates lacking the NesCre transgene.

Student's t tests showed no significant effect of the ER $\beta^{\text {NesCre }}$ mutation on circulating levels of 268 testosterone $\left(\mathrm{t}=0.731, p=0.470, \mathrm{~d}=0.250\right.$ versus $\mathrm{ER} \beta^{\mathrm{fl} / \mathrm{fl}}$; Fig. $\left.1 \mathrm{D}\right)$. This result was corroborated by the unchanged weight of the androgen-dependent seminal vesicles in $\mathrm{ER} \beta^{\mathrm{NesCre}}$ males $(\mathrm{t}=-1.312, p=0.198, \mathrm{~d}=-0.650$ versus controls; Fig. $1 \mathrm{E})$. In fertility tests, $271 \mathrm{ER} \beta^{\mathrm{NesCre}}$ males produced a total number of $45 \pm 5.0$ pups versus $46 \pm 3.0$ for $\mathrm{ER} \beta^{\mathrm{fl} / \mathrm{fl}}$ mice $(\mathrm{t}$

$272=0.083, p=0.936, \mathrm{~d}=0.070)$. The interval from mating to first litter was also similar 273 between the two genotypes $\left(22 \pm 0.4\right.$ days in $\mathrm{ER} \beta^{\mathrm{NesCre}}$ versus $21 \pm 1.0$ days in $\mathrm{ER} \beta^{\mathrm{fl} / \mathrm{fl}} ; \mathrm{t}=$ $0.600, p=0.570, \mathrm{~d}=0.490)$. 
278 Comparable percentages of naïve males ( $86 \%$ of $E R \beta^{\mathrm{fl} / \mathrm{fl}}$ and $81 \%$ of $\mathrm{ER} \beta^{\mathrm{Nes} C r e}$ genotypes) 279 displayed a full range of sexual behavior and reached ejaculation. Analyses of the latencies to 280 the first behaviors showed a significant effect of experience for the latencies to the first mount $281\left(\mathrm{~F}_{(1.28)}=11.240, p=0.002, \eta^{2}=0.141\right)$, pelvic thrusting $\left(\mathrm{F}_{(1,28)}=12.400, p=0.001, \eta^{2}=\right.$ $2820.165)$, intromission $\left(\mathrm{F}_{(1.28)}=13.450, p=0.002, \eta^{2}=0.156\right)$ and latency to ejaculation $\left(\mathrm{F}_{(1.28)}\right.$ $\left.283=14.730, p<0.001, \eta^{2}=0.186\right)$ as illustrated in Fig. 2A. There was no significant effect of 284 genotype on the latencies of these behaviors (mount: $\mathrm{F}_{(1.28)}=2.100, p=0.160, \eta^{2}=0.035$; 285 intromission: $\mathrm{F}_{(1.28)}=2.650, p=0.115, \eta^{2}=0.042$; thrusting: $\mathrm{F}_{(1.28)}=2.890, p=0.100, \eta^{2}=$ 286 0.046; ejaculation: $\left.\mathrm{F}_{(1.28)}=2.960, p=0.096, \eta^{2}=0.043\right)$. The number of mounts without $(\mathrm{M})$ 287 or with intromission (MI), the total number of thrusts and mating length for both naïve and 288 experienced males were also quantified (Table 1). Two-way ANOVA showed a significant 289 effect of experience for the number of thrusts $\left(\mathrm{F}_{(1,28)}=6.920, p=0.014, \eta^{2}=0.105\right)$ and 290 mating length $\left(\mathrm{F}_{(1,28)}=4.520, p=0.042, \eta^{2}=0.070\right)$ but not of genotype $\left(\mathrm{F}_{(1,28)}=0.610, p=\right.$ $2910.441, \eta^{2}=0.010$ and $F_{(1,28)}=0.710, p=0.408, \eta^{2}=0.012$, respectively). There was no 292 significant effect of experience $\left(\mathrm{M}: \mathrm{F}_{(1,28)}=0.250, p=0.622, \eta^{2}=0.005 ; \mathrm{MI}: \mathrm{F}_{(1,28)}=0.850, p\right.$ $\left.293=0.360, \eta^{2}=0.012\right)$ or genotype $\left(\mathrm{M}: \mathrm{F}_{(1,28)}=0.070, p=0.799, \eta^{2}=0.001 ; \mathrm{MI}: \mathrm{F}_{(1,28)}=1.410\right.$, $\left.294 p=0.240, \eta^{2}=0.027\right)$ on the other components of mating.

295 The ability of males to discriminate between male and female pheromones in tests using 296 gonad-intact male versus estrus female was tested. There was a significant effect of stimulus $297\left(\mathrm{~F}_{(1,25)}=7.020, p=0.023, \eta^{2}=0.211\right)$ but not of genotype $\left(\mathrm{F}_{(1,25)}=0.350, p=0.565, \eta^{2}=\right.$ 298 0.011; Fig. 2B). The total time devoted to chemoinvestigation was not significantly different 299 between sexually experienced ER $\beta^{\mathrm{fl} / \mathrm{fl} l}$ and ER $\beta^{\mathrm{NesCre}}$ males $(128.06 \pm 10.35 \mathrm{sec}$ versus 150.38 $300 \pm 12.93 \mathrm{sec}$, respectively; $\mathrm{t}=0.601, p=0.560, \mathrm{~d}=0.360)$. 
304 The ability of males to exhibit a typical female posture after castration and priming with estradiol and progesterone was measured. The percentage of males receiving 20 mounts from experienced intact males over the three tests averaged $50 \%$ in $\mathrm{ER} \beta^{\mathrm{fl} / \mathrm{fl}}$ males and $57 \%$ in $\mathrm{ER} \beta^{\mathrm{NesCre}}$ mice. Only $14 \%$ of $\mathrm{ER} \beta^{\mathrm{fl} / \mathrm{fl}}$ and $16 \%$ of $\mathrm{ER} \beta^{\mathrm{NesCre}}$ genotypes exhibited a lordosis posture. Statistical analysis of the lordosis quotient (LQ) of these males across the three tests showed a significant effect of time $\left(\mathrm{F}_{(2,62)}=4.560, p=0.014, \eta^{2}=0.113\right)$, but not of genotype $\left(\mathrm{F}_{(1,62)}=0.690, p=0.410, \eta^{2}=0.009\right.$; Fig. $\left.2 \mathrm{C}\right)$. The mean LQ of $E R \beta^{\mathrm{fl} / \mathrm{fl}}$ males averaged $15 \%$ at Test 2 but then decreased to $1 \%$ at Test 3 while it was comprised between $2.5 \%$ and $5 \%$ in $\mathrm{ER} \beta^{\mathrm{Nes} C r e}$ mice. To make sure that these low LQ were not due to experimental limitations, we assessed a group of control females in similar conditions. Females exhibited a lordosis behavior with an LQ equivalent to $33.8 \pm 7.6 \%$ since Test 1 ; it increased to reach $71.0 \pm 8.2 \%$ in Test 2 (paired Student's t test, $\mathrm{t}=-3.510, p=0.006, \mathrm{~d}=-4.966$ ).

The males were then subjected to olfactory preference tests. There was no significant effect of stimulus $\left(\mathrm{F}_{(1,33)}=0.050, p=0.825, \eta^{2}=0.002\right)$ or genotype $\left(\mathrm{F}_{(1,33)}=1.210, p=0.290, \eta^{2}=\right.$ 0.033), indicating that males of the two genotypes displayed no olfactory preference (Fig. 2D). The total time spent investigating the two cues was similar between the two genotypes $(117.97 \pm 9.03 \mathrm{sec}$ versus $106.99 \pm 4.98 \mathrm{sec}$, respectively; $\mathrm{t}=1.098, \mathrm{p}=0.290, \mathrm{~d}=0.570)$.

\section{Neuroanatomical organization of the medial preoptic area}

The medial preoptic area, a key target of perinatal estradiol, contains known sexually

324 dimorphic neuronal populations. Global deletion of $E R \beta$ was shown to increase the number of TH neurons in the AVPV, a subdivision of the medial preoptic area, suggesting that ER $\beta$ is 
assessed whether neural $E R \beta$ invalidation alters the neuronatomical organization of $\mathrm{TH}$ -

328 immunoreactive cells. In accordance with previous studies (Simerly et al., 1985), the number 329 of TH-immunoreactive cells was greater (2.4-fold) in females than in $\mathrm{ER}^{\mathrm{fl} / \mathrm{fl}}$ males $(p=$ $330 \quad 0.034$; Fig. $3 \mathrm{~A}$ and C). ER $\beta^{\mathrm{NesCre}}$ males showed a male pattern since no significant differences 331 were seen with their $\operatorname{ER}^{\mathrm{fl} / \mathrm{fl}}$ littermates $(p=0.885)$. The number of kisspeptin332 immunoreactive cells, another sexually dimorphic population, was then quantified in the three 333 subdivisions of the rostral periventricular area of the third ventricle (RP3V). Data show sex 334 differences, with females exhibiting 24 to 225-fold higher number of kisspeptin-ir neurons in 335 the AVPV $(p=0.026)$, rostral $(p=0.034)$ and caudal $(p=0.028)$ periventricular nuclei than $336 \mathrm{ER} \beta^{\mathrm{fl} / \mathrm{fl}}$ males (Fig. 3B and D). Again, no significant differences were observed between $\mathrm{ER} \beta^{\mathrm{fl} / \mathrm{fl}}$ and $\mathrm{ER} \beta^{\mathrm{NesCre}}$ males $(p=0.317, p=0.102$ and $p=0.278$ for the AVPV, rPeN and 338 cPeN, respectively; Fig. 3D).

\section{Quantification of the number of ER $\alpha$ - and AR-immunoreactive cells}

$341 \mathrm{ER} \alpha$ and AR signaling pathways play an important role in the expression of male sexual

342 behavior. It was thus evaluated whether neural $E R \beta$ invalidation altered the number of $E R \alpha-$

343 and AR-immunoreactive cells in the neural circuitry underlying this behavior. The number of

344 ER $\alpha$-immunoreactive cells was unchanged in the MeA $(p=0.275)$ and MPOA $(p=0.513)$ of

$345 \mathrm{ER} \beta^{\mathrm{NesCre}}$ males by comparison to $\mathrm{ER} \beta^{\mathrm{fl} / \mathrm{fl}}$ males (Fig. 4A-B). It was, however, significantly

346 increased by $37 \%$ in the BNST ( $p=0.050$ versus ER $\beta^{\mathrm{fl} / \mathrm{fl}}$ genotype). Similarly, the number of

347 AR-immunoreactive cells was unaltered in the MeA $(p=0.827)$ and MPOA $(p=0.513)$ and

348 significantly increased in the $\mathrm{BNST}$ of $\mathrm{ER} \beta^{\mathrm{NesCre}}$ mice $\left(+38 \%, p=0.050\right.$ versus $\mathrm{ER} \beta^{\mathrm{fl} / \mathrm{fl}}$ 349 genotype; Fig. 5A-B). 
In order to determine the relative contribution of neural sex steroid receptors in reproductive behaviors, a mouse line lacking neural $E R \beta$ was characterized. This genetic model was generated by using the same strategy and NesCre transgene previously described 355 for the mouse line lacking neural $A R$ gene (Raskin et al., 2009). In naïve $\mathrm{ER} \beta^{\mathrm{Nes} C r e}$ males, the latencies and frequencies to perform the various components of copulatory behavior were not statistically different from those observed in their control 358 littermates. Sexual experience ameliorated mating in both $E R \beta^{\mathrm{fl} / \mathrm{fl}}$ and $\mathrm{ER} \beta^{\mathrm{NesCre}}$ males by 359 reducing the latencies to behaviors and mating length, and by increasing the number of 360 thrusts. $E R \beta^{\text {NesCre }}$ males exhibited also normal preference towards female olfactory cues. 361 These results are in agreement with the lack of $\operatorname{ER} \beta$ involvement in the masculinization of 362 sexual behavior and olfactory preference previously reported for the initial global ER $\beta$ 363 knockout model (Kudwa et al., 2005; Ogawa et al., 1999). They contrast with the recent 364 global ER $\beta$ invalidation (Antal et al., 2008), which resulted in increased number of mounts 365 and intromissions and delayed ejaculation, although sexual experience progressively restored 366 these behavioral differences (Antal et al., 2012). As these mice were obtained from the same 367 floxed model and similar genetic background as the present conditional model, we suggest 368 that the mild behavioral deficiency induced by this global mutation was probably due to 369 peripheral effects of $E R \beta$ deletion. The present conditional mutation did not alter male 370 fertility and circulating levels of testosterone while the global $E R \beta$ deletion generated by 371 Chambon's laboratory resulted in an infertile phenotype of unknown origin (Antal et al., 372 2008). Whether or not these global $E R \beta$ knockout males exhibit altered regulation of the 373 hypothalamus-pituitary-gonad axis, which may in turn interfere with reproductive behaviors, 374 has not been reported. In males, ER $\beta$ is expressed in somatic and germ cells of the testis (van 375 Pelt et al., 1999) and seems to be involved in testosterone production (Dumasia et al., 2015). 
377 It has been shown that $E R \beta$ is important in the defeminization processes induced 378 perinatally by estradiol in the neural circuitry underlying male sexual behavior (Kudwa et al., 379 2005). Mutant males from the initial global ERß knockout model (Krege et al., 1998), 380 exhibited a higher lordosis quotient than the wild-type males, after adult castration and 381 priming with estradiol and progesterone. In our conditional model, only a small percentage of $382 \mathrm{ER} \beta^{\mathrm{Nes} C r e}$ males castrated and primed with estradiol and progesterone, showed a lordosis 383 posture. Furthermore, ER $\beta^{\text {NesCre }}$ males exhibiting lordosis behavior displayed a low LQ (5\%) 384 in Test 3 while a mean value of $25 \%$ was reported for global $E R \beta$ knockout mice (Kudwa et al., 2005). Moreover, this low expression of lordosis behavior by $\operatorname{ER} \beta^{\mathrm{NesC} C r}$ males was random across tests, indicating that there was no effect of sexual experience. In similar conditions, a 387 group of control females exhibited a high LQ reaching $71 \%$ since Test 2 . This demonstrates 388 that the low behavior displayed by $\mathrm{ER} \beta^{\mathrm{NesCre}}$ males was not due to experimental limitations.

389 At the neuroanatomical level, the number of TH-ir neurons was not modified in the AVPV of $390 \mathrm{ER} \beta^{\text {NesCre }}$ males. These results contrast with previous studies showing increased number of 391 TH-ir neurons in the AVPV of global ER $\beta$ knockout males (Bodo et al., 2006). However, 392 analysis of kisspeptin neurons, another sexually dimorphic population of the RP3V, 393 confirmed the lack of $E R \beta^{\text {NesCre }}$ mutation effect on the sexual differentiation of the AVPV.

394 The discrepancy between the effects of global versus conditional $E R \beta$ mutation on the 395 behavioral and neuroanatomical defeminization of the AVPV can not be attributed to 396 differences in the genetic background as both models were studied on a C57BL6 background 397 (Bodo et al., 2006; Kudwa et al., 2005). A possible explanation could be that global ER $\beta$ 398 invalidation altered somehow other important pathways such as neural ER $\alpha$ or downstream 399 regulated neurotransmitters or neuropeptides, which in turn interfered with sexual brain 
differentiation. Increased number of TH-ir neurons has been, indeed, reported in the preoptic area of ER $\alpha$ knockout males (Simerly et al., 1997). Alternatively, cell types other than neuronal and glial cells targeted by ER $\beta^{\text {NesCre }}$ could be responsible of the phenotype observed in global ER $\beta$ knockout mice. Microglia cells were recently shown to be important for estradiol-induced sexual differentiation of the preoptic area and copulatory behavior (Lenz et al., 2013).

Neural invalidation of $E R \beta$ resulted in increased number of AR- and ER $\alpha$-immunoreactive neurons specifically in the BNST. Previous studies reported that ER $\beta$ modulates ER $\alpha$ expression in hypothalamic cells (Malikov and Madeira, 2013). Whether ER $\beta$ modulates the expression of both AR and ER $\alpha$ in the BNST needs further investigation. Nevertheless, such cross-regulations between sex steroid receptor signaling pathways are not uncommon since a similar increase of ER $\alpha$-immunoreactive cell number was noticed in the MeA and MPOA of males lacking neural $A R$ (Picot et al., 2014). It is unlikely that the increased amount of AR and $\mathrm{ER} \alpha$ proteins in the BNST compensates for the lack of ER $\beta$ in the expression of sexual behavior. Indeed, $E R \beta$ was deleted along the neural circuitry underlying sexual behavior and 416 no changes in AR- or ER $\alpha$-immunoreactivity were observed in the MeA or MPOA. The 417 BNST is involved in other behaviors such as anxiety-like behavior (Daniel and Rainnie, 2015). Administration of a selective ER $\beta$ agonist to ovariectomized female rats has an 419 anxiolytic effect (Lund et al., 2005; Weiser et al., 2009). This anxiolytic-like effect was 420 observed in wild-type female mice but not in global ERß knockouts (Oyola et al., 2012; Walf et al., 2008), which exhibit increased anxiety-like behavior (Krezel et al., 2001). In agreement with these observations, neural deletion of $E R \beta$ results in increased anxiety-state level during 423 the follicular phase in female mice (Naulé et al., 2015). In male mice, the involvement of ER $\beta$ 424 in estrogen-modulated anxiety state still needs to be documented. Minor effects of gene 
invalidation were reported for global $E R \beta$ knockout males (Krezel et al., 2001), while chronic administration of androgen metabolites with actions at ER $\beta$ decreased the anxiety state level in rats (Osborne et al., 2009). Future studies will address the effects of neural $E R \beta$ deletion on anxiety-like behavior and aggression, another BNST-linked behavior altered in global $E R \beta$ knockout males (Nomura et al., 2002).

These data together with previous studies suggest that testosterone might regulate male sexual behavior mainly through ER $\alpha$ - and AR-signaling pathways. First, global ER $\alpha$ knockout males exhibit a severe sexual deficiency as evidenced by their lack of olfactory cues discrimination and partner preference (Wersinger and Rissman, 2000), increased latencies to mount, thrust and intromit and inability to ejaculate (Ogawa et al., 1997; Ogawa et al., 1998; Wersinger et al., 1997). It remains however to clarify whether the lack of ejaculation can be attributed solely to central effects of $E R \alpha$ mutation since this receptor plays also a role in the physiology of the male urogenital tract (Hess et al., 1997; Joseph et al., 2010). Second, neural invalidation of $A R$ results also in sexual deficiency (Raskin et al., 2009). Unlike global ER $\alpha$ knockout males, males lacking the neural $A R$ exhibit normal olfactory preference and are able to reach ejaculation in the C57BL6/J background, despite longer latencies to initiate the 442 mounting and thrusting behaviors and reduced number of efficient mounts even after a first 443 sexual experience (Picot et al., 2014). Neuroanatomical analyses of sexually dimorphic 444 populations in brain areas underlying reproductive behaviors strongly suggest that the neural $A R$ is not involved in their perinatal organization, but can rather mediate their activation 446 during adulthood (Marie-Luce et al., 2013; Picot et al., 2014). In the spinal sites involved in 447 erection and ejaculation, the neural AR plays a key role in postnatal differentiation and adult 448 maintenance of the spinal nucleus of the bulbocavernosus and gastrin-releasing peptide 449 neuron systems (Raskin et al., 2012; Sakamoto et al., 2014). These data are in good agreement 
with the ontogeny of AR expression showing that this receptor is expressed after the perinatal

451 period in both brain and spinal areas underlying male-typical behavior (Juntti et al., 2010;

452 Smith et al., 2012).

453 Therefore, the ER $\alpha$ may play the main role in the perinatal organization of the brain circuitry

454 underlying sexual behavior. The AR may act postnatally in the spinal cord and lately during 455 pubertal/adult periods at both spinal and brain sites to activate the sexual circuitry. In this 456 context, ER $\beta$ is not required for the organization and activation of sexual behavior. Previous 457 studies suggested a role of this receptor in the timing of male sexual behavior at puberty 458 (Temple et al., 2003). This together with our recent work, showing that neural $E R \beta$ deletion 459 alters the timing of pubertal maturation in females (Naulé et al., 2015), suggest transient 460 prepubertal functions for ER $\beta$ in both sexes. Further studies will characterize the pubertal 461 phenotype of $E R \beta^{\text {NesCre }}$ males.

In conclusion, the evaluation of neural effects of ER $\beta$ by using a conditional knockout 464 model indicates that this receptor is not involved in the masculinization and defeminization of 465 sexual behavior and related brain areas. ER $\alpha$ appears then as the dominant estrogen receptor 466 mediating perinatal effects of estradiol, and AR and ER $\alpha$ might play complementary roles in 467 the full expression of male sexual behavior. Since the ER $\beta^{\mathrm{Nes} C r e}$ mouse line displayed 468 modifications in $\mathrm{ER} \alpha$ and $\mathrm{AR}$ in the BNST, it will be therefore very useful for the 469 investigation of the mechanisms underlying neural ER $\beta$ involvement in mood and aggressive 470 behaviors without interference with male reproductive functions. 


\section{Acknowledgements}

473 We thank Prof. Pierre Chambon (Institut de Génétique et de Biologie Moléculaire et 474 Cellulaire, Illkirch 67404, France) for providing the floxed ER $\beta$ mouse line. This work was 475 supported by the "Contaminants-Ecosystèmes-Santé" program of the "Agence Nationale de la 476 Recherche", "Réseau Santé Environnement Toxicologie" of the "Région Ile de France" and 477 by the CNRS, INSERM and UPMC.

478 


\section{References}

480 Antal, M.C., Krust, A., Chambon, P., Mark, M., 2008. Sterility and absence of histopathological defects in nonreproductive organs of a mouse ERbeta-null mutant. Proc. Natl. Acad. Sci. U.S.A. 105, 2433-2438.

Antal, M.C., Petit-Demoulière, B., Meziane, H., Chambon, P., Krust, A., 2012. Estrogen dependent activation function of ER $\beta$ is essential for the sexual behavior of mouse females. Proc. Natl. Acad. Sci. U.S.A. 109, 19822-19827.

Bodo, C., Kudwa, A.E., Rissman, E.F., 2006. Both estrogen receptor-alpha and -beta are required for sexual differentiation of the anteroventral periventricular area in mice. Endocrinology 147, 415-420.

Clarkson, J., Herbison, A.E., 2006. Postnatal development of kisspeptin neurons in mouse hypothalamus; sexual dimorphism and projections to gonadotropin-releasing hormone neurons. Endocrinology 147, 5817-5825.

Daniel, S.E., Rainnie, D.G., 2015. Stress Modulation of Opposing Circuits in the Bed Nucleus of the Stria Terminalis. Neuropsychopharmacology.

Dumasia, K., Kumar, A., Kadam, L., Balasinor, N.H., 2015. Effect of estrogen receptorsubtype-specific ligands on fertility in adult male rats. J. Endocrinol. 225, 169-180.

Hess, R.A., Bunick, D., Lee, K.H., Bahr, J., Taylor, J.A., Korach, K.S., Lubahn, D.B., 1997. A role for oestrogens in the male reproductive system. Nature 390, 509-512.

Imamov, O., Morani, A., Shim, G.-J., Omoto, Y., Thulin-Andersson, C., Warner, M., Gustafsson, J.-A., 2004. Estrogen receptor beta regulates epithelial cellular differentiation in the mouse ventral prostate. Proc. Natl. Acad. Sci. U.S.A. 101, 93752010. Absence of estrogen receptor alpha leads to physiological alterations in the 
mouse epididymis and consequent defects in sperm function. Biol. Reprod. 82, 948957.

Juntti, S.A., Tollkuhn, J., Wu, M.V., Fraser, E.J., Soderborg, T., Tan, S., Honda, S.-I., Harada, N., Shah, N.M., 2010. The androgen receptor governs the execution, but not programming, of male sexual and territorial behaviors. Neuron 66, 260-272.

Kauffman, A.S., Gottsch, M.L., Roa, J., Byquist, A.C., Crown, A., Clifton, D.K., Hoffman, G.E., Steiner, R.A., Tena-Sempere, M., 2007. Sexual differentiation of Kiss1 gene expression in the brain of the rat. Endocrinology 148, 1774-1783.

Keller, M., Douhard, Q., Baum, M.J., Bakker, J., 2006. Sexual experience does not compensate for the disruptive effects of zinc sulfate--lesioning of the main olfactory epithelium on sexual behavior in male mice. Chem. Senses 31, 753-762.

Krege, J.H., Hodgin, J.B., Couse, J.F., Enmark, E., Warner, M., Mahler, J.F., Sar, M., Korach, K.S., Gustafsson, J.A., Smithies, O., 1998. Generation and reproductive phenotypes of mice lacking estrogen receptor beta. Proc. Natl. Acad. Sci. U.S.A. 95, 15677-15682.

Krezel, W., Dupont, S., Krust, A., Chambon, P., Chapman, P.F., 2001. Increased anxiety and synaptic plasticity in estrogen receptor beta -deficient mice. Proc. Natl. Acad. Sci. U.S.A. $98,12278-12282$.

Kudwa, A.E., Bodo, C., Gustafsson, J.-A., Rissman, E.F., 2005. A previously uncharacterized role for estrogen receptor beta: defeminization of male brain and behavior. Proc. Natl. Acad. Sci. U.S.A. 102, 4608-4612.

Lenz, K.M., Nugent, B.M., Haliyur, R., McCarthy, M.M., 2013. Microglia are essential to masculinization of brain and behavior. J. Neurosci. 33, 2761-2772.

Lund, T.D., Rovis, T., Chung, W.C.J., Handa, R.J., 2005. Novel actions of estrogen receptorbeta on anxiety-related behaviors. Endocrinology 146, 797-807. 
Malikov, V., Madeira, M.D., 2013. Regulation of ER $\alpha$ protein expression by $17 \beta$-estradiol in cultured neurons of hypothalamic ventromedial nucleus. Neurochem. Res. 38, 82-89.

Marie-Luce, C., Raskin, K., Bolborea, M., Monin, M., Picot, M., Mhaouty-Kodja, S., 2013. Effects of neural androgen receptor disruption on aggressive behavior, arginine vasopressin and galanin systems in the bed nucleus of stria terminalis and lateral septum. Gen. Comp. Endocrinol. 188, 218-225.

Naulé, L., Picot, M., Martini, M., Parmentier, C., Hardin-Pouzet, H., Keller, M., Franceschini, I., Mhaouty-Kodja, S., 2014. Neuroendocrine and behavioral effects of maternal exposure to oral bisphenol A in female mice. J. Endocrinol. 220, 375-388.

Naulé, L., Robert, V., Parmentier, C., Martini, M., Keller, M., Cohen-Solal, M., HardinPouzet, H., Grange-Messent, V., Franceschini, I., Mhaouty-Kodja, S., 2015. Delayed pubertal onset and prepubertal Kiss1 expression in female mice lacking central oestrogen receptor beta. Hum. Mol. Genet. Oct 12. pii: ddv430. [Epub ahead of print]

Nomura, M., Durbak, L., Chan, J., Smithies, O., Gustafsson, J.-A., Korach, K.S., Pfaff, D.W., Ogawa, S., 2002. Genotype/age interactions on aggressive behavior in gonadally intact estrogen receptor beta knockout (betaERKO) male mice. Horm Behav 41, 288-296.

Ogawa, S., Chan, J., Chester, A.E., Gustafsson, J.A., Korach, K.S., Pfaff, D.W., 1999. Survival of reproductive behaviors in estrogen receptor beta gene-deficient (betaERKO) male and female mice. Proc. Natl. Acad. Sci. U.S.A. 96, 12887-12892.

Ogawa, S., Lubahn, D.B., Korach, K.S., Pfaff, D.W., 1997. Behavioral effects of estrogen receptor gene disruption in male mice. Proc. Natl. Acad. Sci. U.S.A. 94, 1476-1481.

Ogawa, S., Washburn, T.F., Taylor, J., Lubahn, D.B., Korach, K.S., Pfaff, D.W., 1998. Modifications of testosterone-dependent behaviors by estrogen receptor-alpha gene disruption in male mice. Endocrinology 139, 5058-5069. 
Orikasa, C., Sakuma, Y., 2010. Estrogen configures sexual dimorphism in the preoptic area of C57BL/6J and ddN strains of mice. J. Comp. Neurol. 518, 3618-3629.

Osborne, D.M., Edinger, K., Frye, C.A., 2009. Chronic administration of androgens with actions at estrogen receptor beta have anti-anxiety and cognitive-enhancing effects in male rats. Age (Dordr) 31, 191-198.

Oyola, M.G., Portillo, W., Reyna, A., Foradori, C.D., Kudwa, A., Hinds, L., Handa, R.J., Mani, S.K., 2012. Anxiolytic effects and neuroanatomical targets of estrogen receptor$\beta$ (ER $\beta$ ) activation by a selective ER $\beta$ agonist in female mice. Endocrinology 153, $837-846$.

Paxinos, G., Franklin, K.B.J., 2001. The mouse brain in stereotaxic coordinates, Second Edition. Academic Press.

Picot, M., Naulé, L., Marie-Luce, C., Martini, M., Raskin, K., Grange-Messent, V., Franceschini, I., Keller, M., Mhaouty-Kodja, S., 2014. Vulnerability of the neural circuitry underlying sexual behavior to chronic adult exposure to oral bisphenol a in male mice. Endocrinology 155, 502-512.

Raskin, K., de Gendt, K., Duittoz, A., Liere, P., Verhoeven, G., Tronche, F., Mhaouty-Kodja, S., 2009. Conditional inactivation of androgen receptor gene in the nervous system: effects on male behavioral and neuroendocrine responses. J. Neurosci. 29, 4461-4470.

Raskin, K., Marie-Luce, C., Picot, M., Bernard, V., Mailly, P., Hardin-Pouzet, H., Tronche, F., Mhaouty-Kodja, S., 2012. Characterization of the spinal nucleus of the bulbocavernosus neuromuscular system in male mice lacking androgen receptor in the nervous system. Endocrinology 153, 3376-3385.

Sakamoto, H., Saito, K., Marie-Luce, C., Raskin, K., Oti, T., Satoh, K., Tamura, K., Sakamoto, T., Mhaouty-Kodja, S., 2014. Androgen regulates development of the sexually dimorphic gastrin-releasing peptide neuron system in the lumbar spinal cord: 
evidence from a mouse line lacking androgen receptor in the nervous system. Neurosci. Lett. 558, 109-114.

Sar, M., Welsch, F., 2000. Oestrogen receptor alpha and beta in rat prostate and epididymis. Andrologia 32, 295-301.

Saunders, P.T., Fisher, J.S., Sharpe, R.M., Millar, M.R., 1998. Expression of oestrogen receptor beta (ER beta) occurs in multiple cell types, including some germ cells, in the rat testis. J. Endocrinol. 156, R13-17.

Schwarz, JM., McCarthy, M.M., 2008. Cellular mechanisms of estradiol-mediated masculinization of the brain. J Steroid Biochem Mol Biol. 109, 300-306.

Simerly, R.B., Swanson, L.W., Gorski, R.A., 1985. The distribution of monoaminergic cells

Temple, J.L., Fugger, H.N., Li, X., Shetty, S.J., Gustafsson, J., Rissman, E.F., 2001. Estrogen

Smith, M.R., Hamson, D.K., Poort, J.E., Jordan, C.L., Breedlove, S.M., 2012. Ontogeny of androgen receptor expression in spinal nucleus of the bulbocavernosus motoneurons and their target muscles in male mice. Neurosci. Lett. 513, 119-123.

Snyder, M.A., Smejkalova, T., Forlano, P.M., Woolley, C.S., 2010. Multiple ERbeta antisera label in ERbeta knockout and null mouse tissues. J. Neurosci. Methods. 188, 226-234. receptor beta regulates sexually dimorphic neural responses to estradiol. Endocrinology 142, 510-513. 
601 Temple, J.L., Scordalakes, E.M., Bodo, C., Gustafsson, J.A., Rissman, E.F., 2003. Lack of

602

603

604

605

606

607

608

609

610

611

612

613

614

615

616

617

618

619

620

621

622

623

624 functional estrogen receptor beta gene disrupts pubertal male sexual behavior. Horm Behav 44, 427-434.

Tsukahara, S., Tsuda, M.C., Kurihara, R., Kato, Y., Kuroda, Y., Nakata, M., Xiao, K., Nagata, K., Toda, K., Ogawa, S., 2011. Effects of aromatase or estrogen receptor gene deletion on masculinization of the principal nucleus of the bed nucleus of the stria terminalis of mice. Neuroendocrinology 94, 137-147.

Van Pelt, A.M., de Rooij, D.G., van der Burg, B., van der Saag, P.T., Gustafsson, J.A., Kuiper, G.G., 1999. Ontogeny of estrogen receptor-beta expression in rat testis. Endocrinology 140, 478-483.

Wahlgren, A., Svechnikov, K., Strand, M.-L., Jahnukainen, K., Parvinen, M., Gustafsson, J.A., Söder, O., 2008. Estrogen receptor beta selective ligand 5alpha-Androstane-3beta, 17beta-diol stimulates spermatogonial deoxyribonucleic acid synthesis in rat seminiferous epithelium in vitro. Endocrinology 149, 2917-2922.

Walf, A.A., Ciriza, I., Garcia-Segura, L.M., Frye, C.A., 2008. Antisense oligodeoxynucleotides for estrogen receptor-beta and alpha attenuate estradiol's modulation of affective and sexual behavior, respectively. Neuropsychopharmacology $33,431-440$.

Weiser, M.J., Wu, T.J., Handa, R.J., 2009. Estrogen receptor-beta agonist diarylpropionitrile: biological activities of $\mathrm{R}$ - and S-enantiomers on behavior and hormonal response to stress. Endocrinology 150, 1817-1825.

Wersinger, S.R., Rissman, E.F., 2000. Oestrogen receptor alpha is essential for femaledirected chemo-investigatory behaviour but is not required for the pheromone-induced luteinizing hormone surge in male mice. J. Neuroendocrinol. 12, 103-110. 
625 Wersinger, S.R., Sannen, K., Villalba, C., Lubahn, D.B., Rissman, E.F., De Vries, G.J., 1997. 626 Masculine sexual behavior is disrupted in male and female mice lacking a functional 627 estrogen receptor alpha gene. Horm Behav 32, 176-183.

628 
Fig. 1. Characterization of the ER $\boldsymbol{\beta}^{\text {NesCre }}$ mouse line. (A) RT-PCR of total RNAs obtained

631 from the brain $(\mathrm{Br})$ and epididymis (Ep). The representative gel shows the presence of the 177

632 base pair (bp) amplified fragment in the epididymis of both genotypes and only in the brain of 633 control ER $\beta^{\mathrm{fl} / f l}$ males. DNA size markers at $50 \mathrm{bp}$ increments are shown in the left column.

634 (B) Quantitative data normalized to GAPDH from 3 males per genotype. ${ }^{* *} p<0.01$ versus $635 \mathrm{ER} \beta^{\mathrm{fl} / \mathrm{fl}}$ brain. (C) PCR analyses performed on the brain of three neonates and four adults, 636 obtained from the same litters, respectively. Up: PCR analysis showing the presence of the 637 floxed ER $\beta$ allelle $(850 \mathrm{bp})$ in the neonatal and adult brain of $\operatorname{ER} \beta^{\mathrm{fl} / \mathrm{fl}}$ mice $(2,3,5,7)$. The 638 small amplicon of 250 base pair (bp) indicating Cre-mediated excision of exon 3 was present 639 in the neonatal and adult brain of ER $\beta^{\text {NesCre }}$ littermates $(1,4,6)$. Down: PCR analysis showing 640 the presence of Cre recombinase in the neonatal and adult brain of ER $\beta^{\mathrm{NesCre}}$ mice expressing 641 the excised $E R \beta$ allele $(1,4,6)$. DNA size markers at $100 \mathrm{bp}$ increments are shown in the left 642 column. (D) Circulating levels of testosterone in $E R \beta^{\mathrm{fl} / \mathrm{fl}}$ and $\mathrm{ER} \beta^{\mathrm{NesCre}}$ males $(\mathrm{n}=10$ per 643 genotype). (E) Weight of seminal vesicles (SV) expressed as percentage of body weight (bw) 644 in male mice $(\mathrm{n}=10$ per genotype).

645

Fig. 2. Effects of neural $E R \beta$ invalidation on sexual behavior and olfactory preference in

647 males. (A) Latencies to the first mount (Mo), thrust (Th), intromission (In), and ejaculation $648(\mathrm{Ej})$ of intact $\mathrm{ER} \beta^{\mathrm{fl} / \mathrm{fl}}$ and $\mathrm{ER} \beta^{\mathrm{NesCre}}$ males in Tests 1 and $2(\mathrm{n}=13-17$ animals per genotype). $649{ }^{\mathrm{a}} p<0.05$ versus Test 2. (B) Time spent chemoinvestigating gonad-intact male (M) versus 650 estrus female $(\mathrm{F})$ expressed as percentage of the total time chemoinvestigating $(\mathrm{n}=9-10$ 651 males per genotype). ${ }^{\mathrm{a}} p<0.05$ versus female stimulus. (C) Lordosis quotient of castrated 652 males supplemented with estradiol and progesterone in three successive tests $(n=6-10$ males 653 per genotype). (D) Time spent chemoinvestigating intact males (M) versus estrus females (F), 
654 expressed as percentage of total time spent chemoinvestigating, after castration and 655 supplementation with estradiol and progesterone $(n=9-10$ per genotype).

656

657 Fig. 3. Tyrosine hydroxylase (TH) and kisspeptin immunoreactivity in ER $\beta^{\text {fl/fl } \text { and }}$ $658 \mathbf{E R} \boldsymbol{\beta}^{\text {NesCre }}$ males. (A-B) Representative immunostaining of TH (A) and kisspeptin (B) in $659 \mathrm{ER} \beta^{\mathrm{fl} / \mathrm{fl}}$ males, their mutant littermates $\left(\mathrm{ER} \beta^{\mathrm{NesCre}}\right)$ males and in control females. Scale bar $=$ $660100 \mu \mathrm{m}$. (C-D) Quantitative data for TH- in the anteroventral periventricular nucleus (AVPV) 661 (C) and kisspeptin-immunoreactivity in the AVPV, rostral (rPeN) and caudal (cPeN) 662 periventricular nuclei (D) are expressed as mean values \pm S.E.M for 4 animals per group. ${ }^{a} p<$ 6630.05 versus $\mathrm{ER} \beta^{\mathrm{fl} / \mathrm{fl}}$ males.

664

Fig. 4. Quantification of ER $\alpha$-immunoreactive cell number in brain areas of $E R \beta^{f / / f l}$ and

$\mathbf{E R} \boldsymbol{\beta}^{\text {NesCre }}$ males. (A) Representative anti-ER $\alpha$ immunostaining in the medial amygdala 667 (MeA), bed nucleus of the stria terminalis (BNST) and medial preoptic area (MPOA) of $\mathrm{ER} \beta^{\mathrm{fl} / \mathrm{fl}}$ and $\mathrm{ER} \beta^{\mathrm{NesCre}}$ males. Scale bar $=100 \mu \mathrm{m} . \mathrm{AC}$, anterior commissure. $(\mathbf{B})$ Quantitative 669 data for the number of ER $\alpha$-immunoreactive (ir) cells are expressed as mean values \pm S.E.M 670 for 3-4 animals per genotype. ${ }^{\mathrm{a}} p<0.05$ versus ER $\beta^{\mathrm{fl} / \mathrm{fl}}$ males in the BNST.

672 Fig. 5. Quantification of AR-immunoreactive cell number in brain areas of $\mathbf{E R} \beta^{\mathrm{fl} / \mathrm{fl}}$ and

$673 \mathbf{E R} \boldsymbol{\beta}^{\text {NesCre }}$ males. (A) Representative anti-AR immunostaining in the medial amygdala 674 (MeA), bed nucleus of the stria terminalis (BNST) and medial preoptic area (MPOA) of $675 \mathrm{ER} \beta^{\mathrm{fl} / f \mathrm{l}}$ and $\mathrm{ER} \beta^{\mathrm{NesCre}}$ males. Scale bar $=100 \mu \mathrm{m} . \mathrm{AC}$, anterior commissure. $(\mathbf{B})$ Quantitative 676 data for the number of AR-immunoreactive (ir) cells are expressed as mean values \pm S.E.M 677 for 3-4 animals per genotype. ${ }^{\mathrm{a}} p<0.05$ versus ER $\beta^{\mathrm{fl} / \mathrm{fl}}$ males in the BNST.

\section{Table legends.}


679 Table 1. Quantification of the sexual behavior displayed by naïve and sexually 680 experienced $\mathbf{E R} \boldsymbol{\beta}^{\text {fl/fl }}$ and $\mathbf{E R} \boldsymbol{\beta}^{\text {NesCre }}$ males. The number of mounts without (M) or with 681 intromission (MI), the total number of thrusts (Th) and mating length are shown for males (n $682=13-17$ per genotype) tested in Tests 1 and Test $2 .{ }^{\mathrm{a}} p<0.05$ versus Test 1.

683 
A
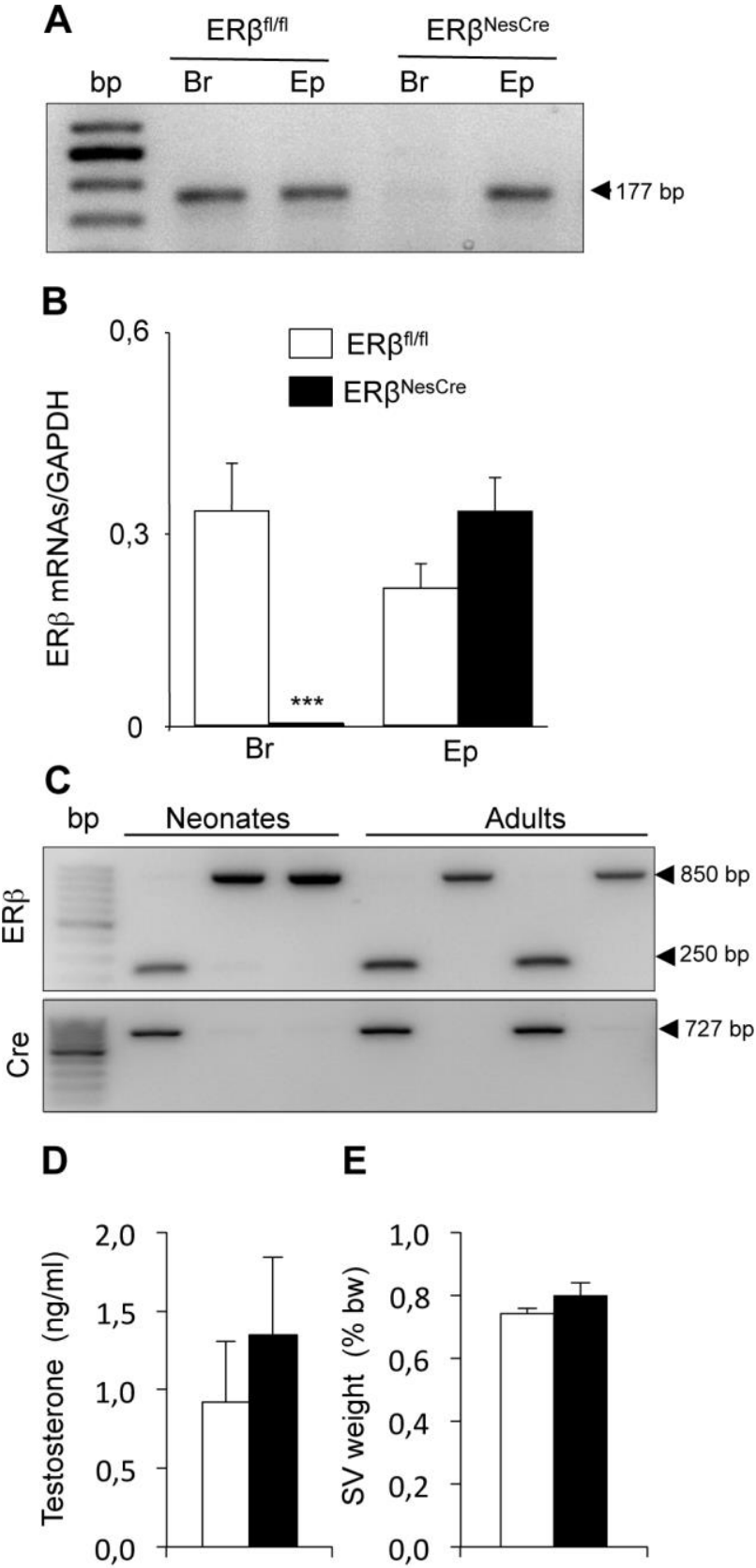

684

Figure 1

685 
A

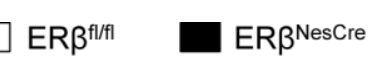

B
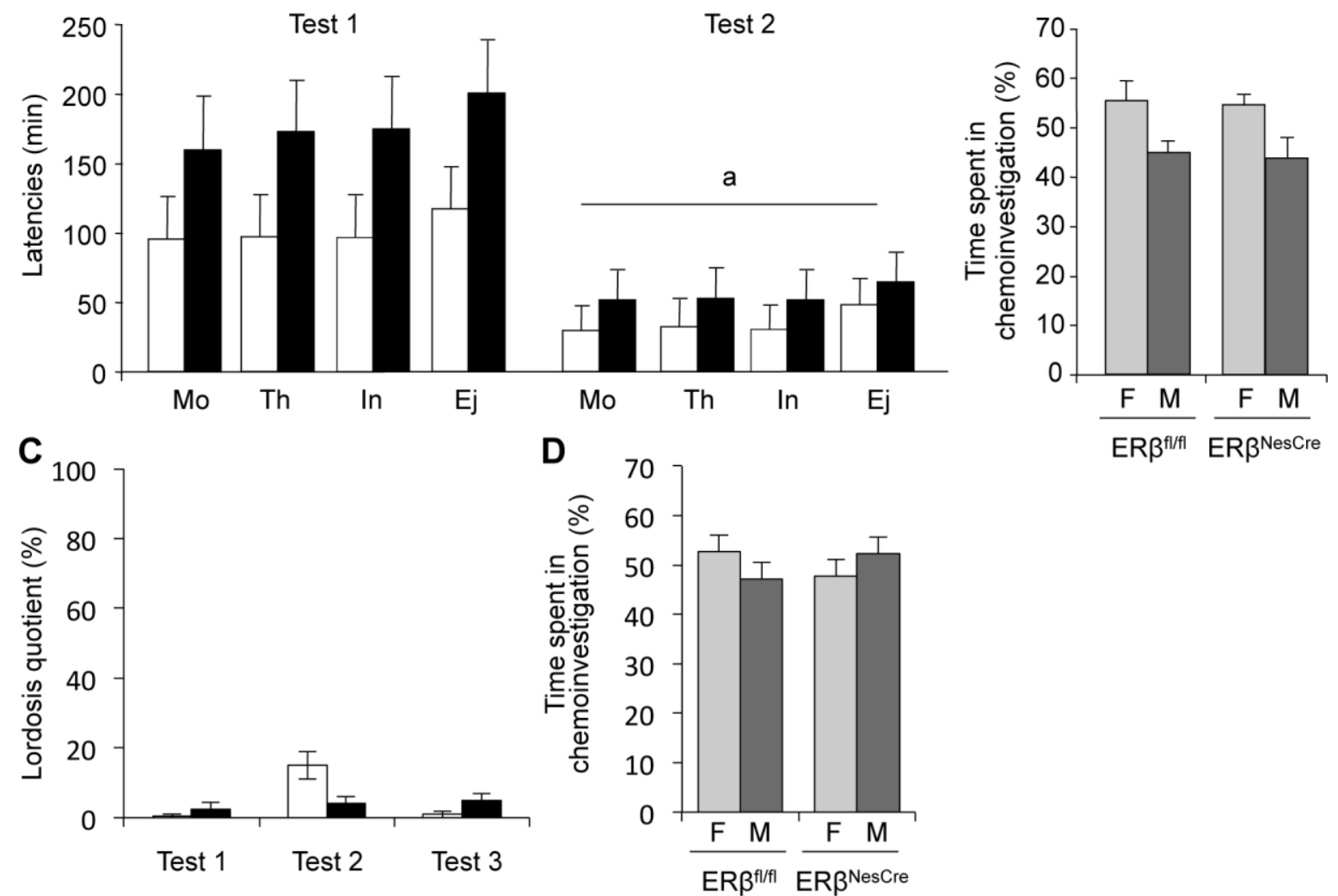

686

Figure 2

687 
A

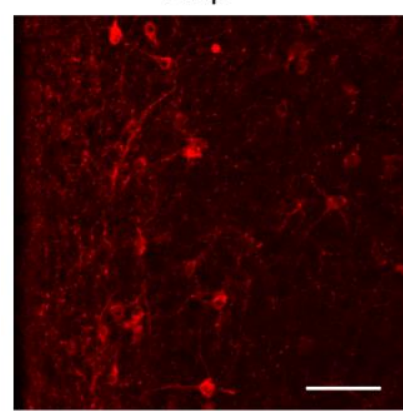

B $\quad E R \beta^{\text {fl/fI }}$

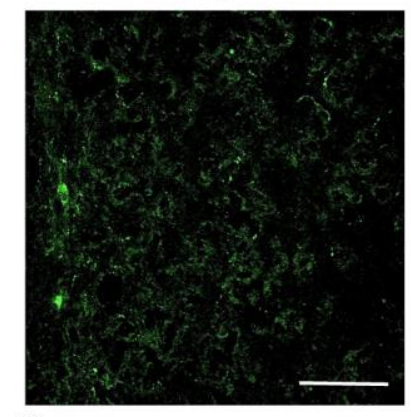

C

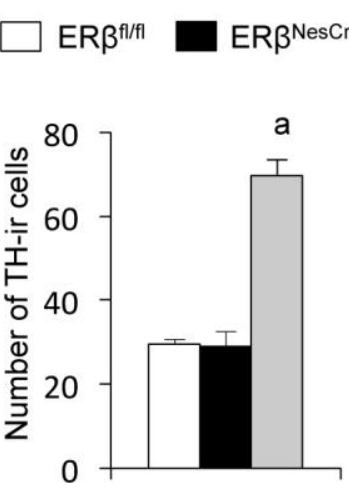

688
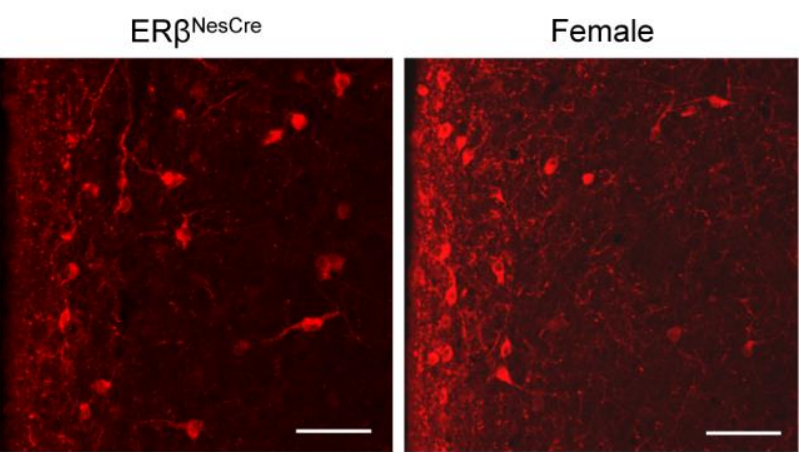

ER $\beta^{\text {NesCre }}$

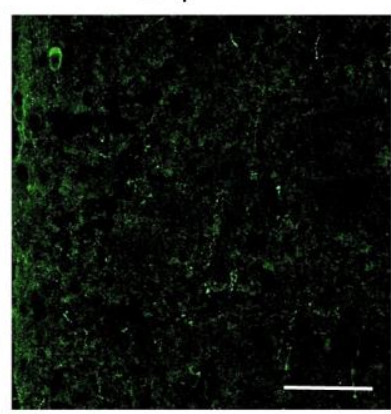

Female

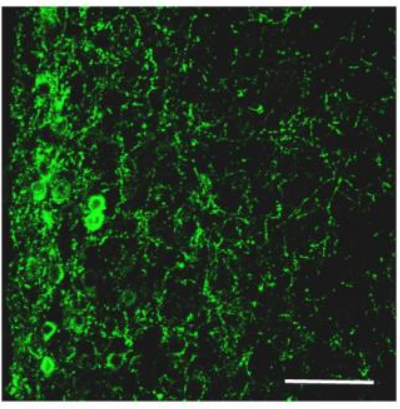

D

\section{e}

\begin{tabular}{ll} 
을 & 180 \\
\hline$\overline{0}$ & 170
\end{tabular}

旁 160

言 150

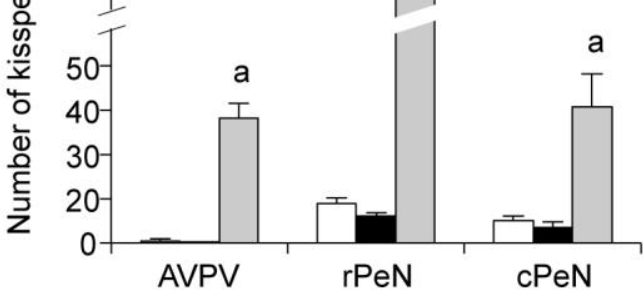

Figure 3

689 
A

$E R \beta^{f / / f l}$

$\stackrel{\nwarrow}{\Perp}$

占

AC

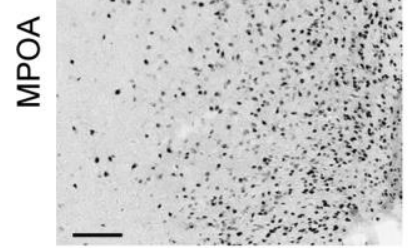

ER $\beta^{\text {NesCre }}$
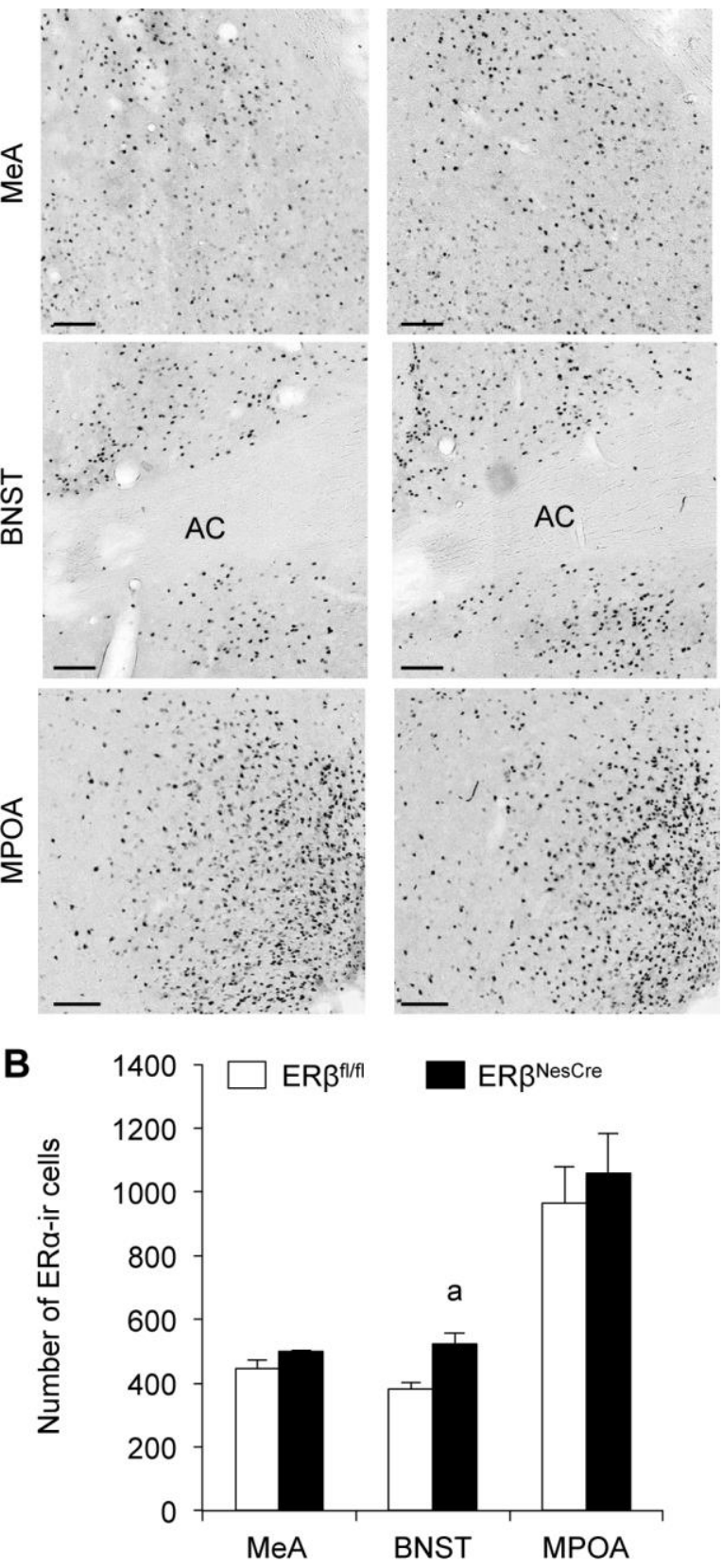

Figure 4 

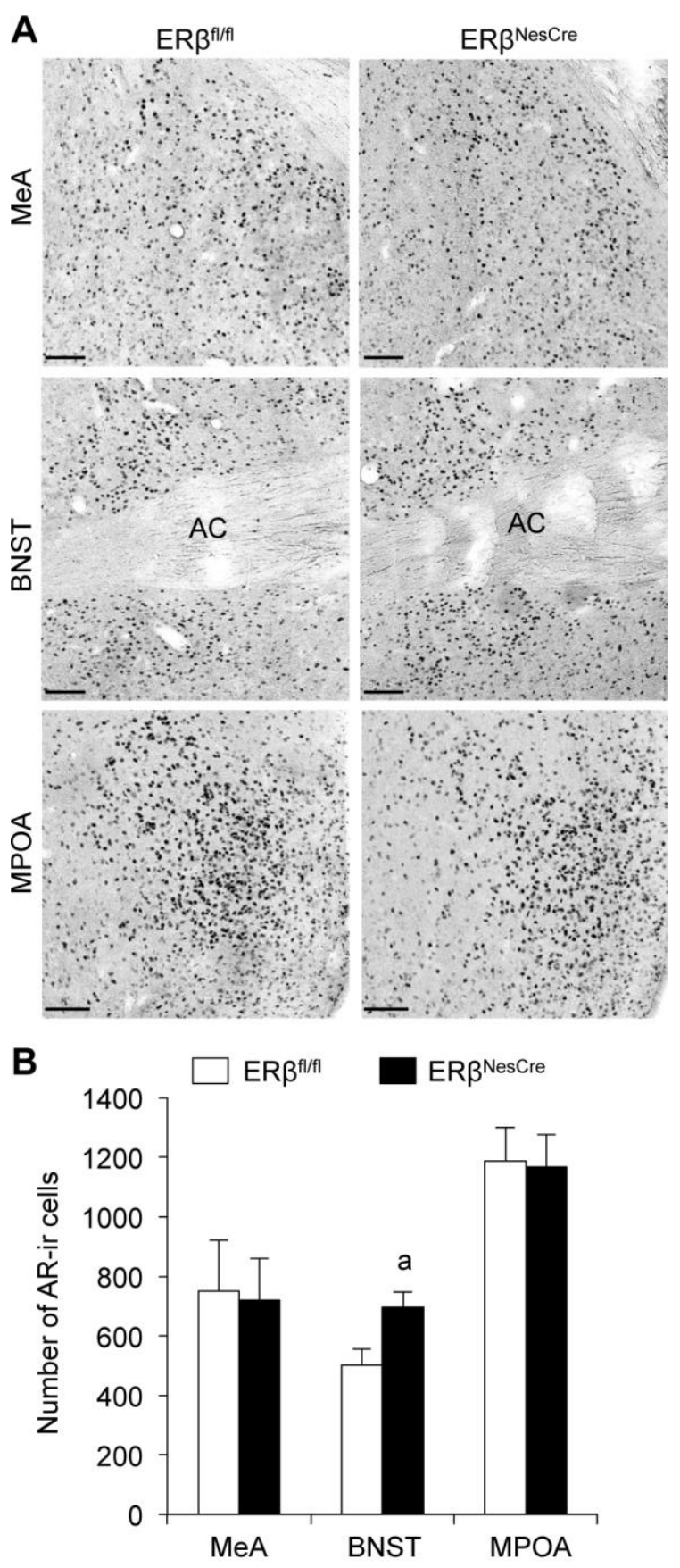